\title{
Isolation and presumptive serological characterization of hantavirus from wild rat (Bandicota indica)
}

\author{
Praseno*, Suwarso ${ }^{* *}$
}

\begin{abstract}
Abstrak
Hantavirus termasuk dalam kelompok famili Bunyaviridae dan ditemukan di banyak bagian dunia. Secara klasik, infeksi Hantavirus dihubungkan dengan Hemorrhagic fever with Renal Syndrome (HFRS), meskipun gejala klinik sangat beragam. Karena pembawa utama dari Hantavirus adalah tikus, maka survei secara serologik dilakukan pada tikus liar (Bandicota indica) di kota Yogyakarta. Isolasi virus dilakukan untuk memastikan keberadaan hantavirus. Hasil yang didapat menunjukkan bahwa, dengan teknik imunofluoresensi antibodi, tingkat seropositif adalah 30\%. Hantavirus telah diisolasi dari jaringan paru tikus. Secara serologik virus tersebut berhubungan dekat dengan virus Hantaan atau Seoul. Sampai saat ini makna klinik infeksi hantavirus di Yogyakarta belum diketahui dan memerlukan penelitian lebih lanjut. Keberadaan Hantavirus ini kemungkinan dapat menjadi masalah infeksi viral yang
akan muncul di Indonesia.
\end{abstract}

\begin{abstract}
Hantavirus is a newly established genus of the family Bunyaviridae and found in many parts of the world. Classically, infection with hantavirus is associated with hemorrhagic fever with renal syndrome (HFRS) although clinical features vary considerably. Since the main reservoir of hantavirus is rodents, serological survey was conducted in wild urban rats (Bandicota indica) in Yogyakarta municipality. Viral isolation was performed to establish the existence of the virus. Results showed that, by immunofluorescence antibody technique, overall seropositive rate was $30 \%$. Hantavirus was isolated from lung tissue of the animal. Serologically, hantavirus infecting these rats is closely related to Hantaan or Seoul virus. So far clinical significance of hantavirus in Indonesia is not yet known and warrants further investigations. It is likely that the presence of the virus could be an emerging viral infection problem in Indonesia.
\end{abstract}

Keywords: hantavirus, Bandicota indica, hemorrhagic fever with renal syndrome

\section{INTRODUCTION}

Hantavirus is a newly established genus of the family Bunyaviridae which is found mainly in Asia and eastern parts of Europe. At least seven different strains of hantavirus have been recognized, including Hantaan, Seoul, Puumula, Belgrade, Prospect Hill, and Leaky virus.

Prototype of hantavirus, Hantaan virus, was known to be the etiologic agent of Korean Hemorrhagic Fever (KHF). In 1982 The WHO recommended to use "Hemorrhagic Fever with Renal Syndrome" (HFRS) instead of KHF and KHF-like diseases for infection caused by Hantaan and Hantaan-related virus. ${ }^{2}$

\footnotetext{
* Department of Microbiology Faculty of Medicine, Gadjah Mada University, Yogyakarta, Indonesia

** Department of Clinical Pathology Faculty of Medicine, Gadjah Mada University, Yogyakarta, Indonesia
}

Specifically, the disease is characterized by abrupt onset of high fever, various hemorrhagic manifestations and transient renal and hepatic disfunctions. However, the clinical spectrum of Hantavirus infection varies greatly, including 'flu-like illness', acute renal failure, acute abdomen, acute respiratory distress syndrome, and disseminated intravascular coagulation. ${ }^{3}$

More recenty, a novel hantavirus called Sin Nombre virus has been isolated in United States. This virus is associated with acute respiratory distress syndrome with mortality rate of 70 percent. ${ }^{4,5}$

All hantaviruses are spread by rodents where the major route of transmission is via aerosol of rodent urine, saliva, and faeces. ${ }^{6}$

While there have been many cases of hemorrhagic fever and renal syndrome in Indonesia, the role of hantavirus in these cases is not known. This is, in part, 
because of unawareness of the clinicians about the virus and the lack of diagnostic kit for laboratory diagnosis of infection with hantavirus in Indonesia. Since cases of HFRS have been reported in Thailand, Phillipine, and Malaysia it is very likely that infection with the virus have also occured in Indonesia.

So far, there is no data on seroepidemiological study of infection with hantavirus in urban rats of Bandicota indica in Indonesia. This study is very important in providing information about the extent of the reservoir in these rodents. Isolation of the virus will establish the existence of hantavirus in Indonesia.

\section{MATERIALS AND METHODS}

\section{Preparation of sera from wild rats (Bandicota indica)}

Wild rats were captured by trapping the animal along a river-side in the center of Yogyakarta municipality. Blood was taken from these rats and sera were separated from the clot and stored at - $20 \mathrm{C}$ until used. Lungs of the animal were collected and kept frozen at $-70^{\circ} \mathrm{C}$ for further viral isolation experiments.

\section{Preparation of viral antigen}

Vero E6 cell line infected with Hantaan, Seoul, Puumula, and Sin Nombre virus, respectively were cultured in Eagle Minimal Essential Medium (EMEM) supplemented with $10 \%$ fetal calf serum (FCS) and antibiotic. ${ }^{7}$ After 12 days of incubation at $37^{\circ} \mathrm{C}$ in a humidified $\mathrm{CO} 2$ incubator cultures were trypsinized and harvested. Cells were washed with phosphate-buffered saline (PBS) and resuspended in EMEM supplemented with $5 \%$ FCS. The suspension was then distributed on to wells of teflon-coated glass slides and fixed with aceton. After fixation the slides was stored at $-70^{\circ} \mathrm{C}$ until used.

\section{Detection of specific antibody to hantaviruses by indirect immunofluorescence antibody technique}

Sera of Bandicota indica were diluted 1:32 with PBS. Each of $25 \mu 1$ of these diluted sera were dropped on to wells of slides on which viral antigens were fixed (Hantaan, Seoul, Puumula, and Sin Nombre virus, respectively). Slides were incubated at $37^{\circ} \mathrm{C}$ in a humid chamber for 30 minutes. After incubation slides were washed with PBS for 5 minutes and dried at room temperature. $25 \mu$ of FITC-labeled rabbit anti-rat IgG was added on to wells and the slides reincubated for 30 minutes. After washing and drying, small drops of mounting fluid applied on to wells, the slides covered with coverslips and examined under fluorescence microscope. The presence of cytoplasmic granules with greenish-yellow color was recorded as a positive result.

\section{Titration of the animals sera}

Positive sera were further diluted 1:128, 1:512, 1:2048, and 1:8192. These sera were examined as previously described. Determination of titer of the antibody to these four different strains of hantaviruses is used to presumptively identify the newly isolated hantavirus.

\section{Viral isolation}

Lungs from the animal showing antibody titer greater than 512 were used as starting material for the isolation. The lungs were minced and suspended as $20 \%$ w/v in MEM suplemented with $10 \%$ FCS and antibiotic. The suspension was allowed to stand for 10 minutes to settle larger tissue fragments. $1 \mathrm{ml}$ of the suspension was then inoculated into confluent monolayer growth of Vero E6 cell culture. After 10 days incubation the cells was harvested and suspended in fresh growth medium (MEM with 10\% FCS). While suspended, slide was prepared and examined for the presence of viral antigen by immunofluorescence assay as previously described using known positive serum to Hantaan virus. Suspended cells were further cultured and examination of viral antigen was performed after additional 5 days incubation.

\section{RESULTS}

Two hundreds wild rats were captured and used in this study. Seropositive to Hantaan, Seoul, Puumula, and Sin Nombre virus were found in rats with different rates (Table 1).

Table 1. Seropositive rates of antibody to four different strains of hantaviruses in Bandicota indica

\begin{tabular}{cccc}
\hline \multicolumn{4}{c}{ Number of animals seropositive to strains of } \\
HANTAAN & SEOUL & PUUMULA & SIN NOMBRE \\
\hline 60 & 50 & 27 & 21 \\
$(30 \%)$ & $(25 \%)$ & $(13,5 \%)$ & $(10,5 \%)$ \\
\hline
\end{tabular}


It should be noted that a serum sample may react to three or all of these viruses. Titers of the antibody to Hantaan, Seoul, Puumula, and Sin Nombre were in the range of 32-8912, 32-8912, 32-2048, and 32-512, respectively (Table 2 ).

Table 2. Antibody titers of Bandicota indica to strains of hantaviruses

\begin{tabular}{lc}
\hline Strains of hantavirus & $\begin{array}{c}\text { Titer of antibody* } \\
\text { (range) }\end{array}$ \\
\hline Hantaan & $32-8192$ \\
Seoul & $32-8192$ \\
Puumula & $32-512$ \\
Sin Nombre & $32-2048$ \\
\hline
\end{tabular}

* reciprocal titer

Viral antigen expression was observed after 10 days incubation of infected Vero E6 cell culture. Immunofluorescence staining of infected cells will show characteristics greenish-yellow intracytoplasmic granules (Figure 1).

\section{DISCUSSION}

Isolation of Hantaan virus and development of serodiagnostic test has led to the recognition that hantaviruses are widely spread throughout the world. Urban rats infected with hantavirus have been reported in 10 Asian countries (Japan, Korea, China, Hongkong, India, Sri Lanka, The Philippines, Fiji, Singapore, and Malaysia). ${ }^{1}$ Using immunofluorescence antibody technique, seropositive rate of hantavirus infection in rodents in Singapore was $26 \% .^{8}$ Our study show that overall seropositive rate in Bandicota indica was $30 \%$. The animals was seropositive to four different strains of the virus and this is not uncommon as there is serological cross reactivity among strains of hantaviruses. From titration of the sera it seems that the virus is more closely related to Hantaan or Seoul virus. Further investigation is still needed to determine identity of the virus in these animals using monoclonal antibody or nucleotide sequence analysis.

Our study obviously showed that hantavirus exists in Yogyakarta. However, clinical significance of the virus is not yet known. It is very likely that infection with the virus do result in clinical signs and symptoms resemble to those of other viral or bacterial infections.

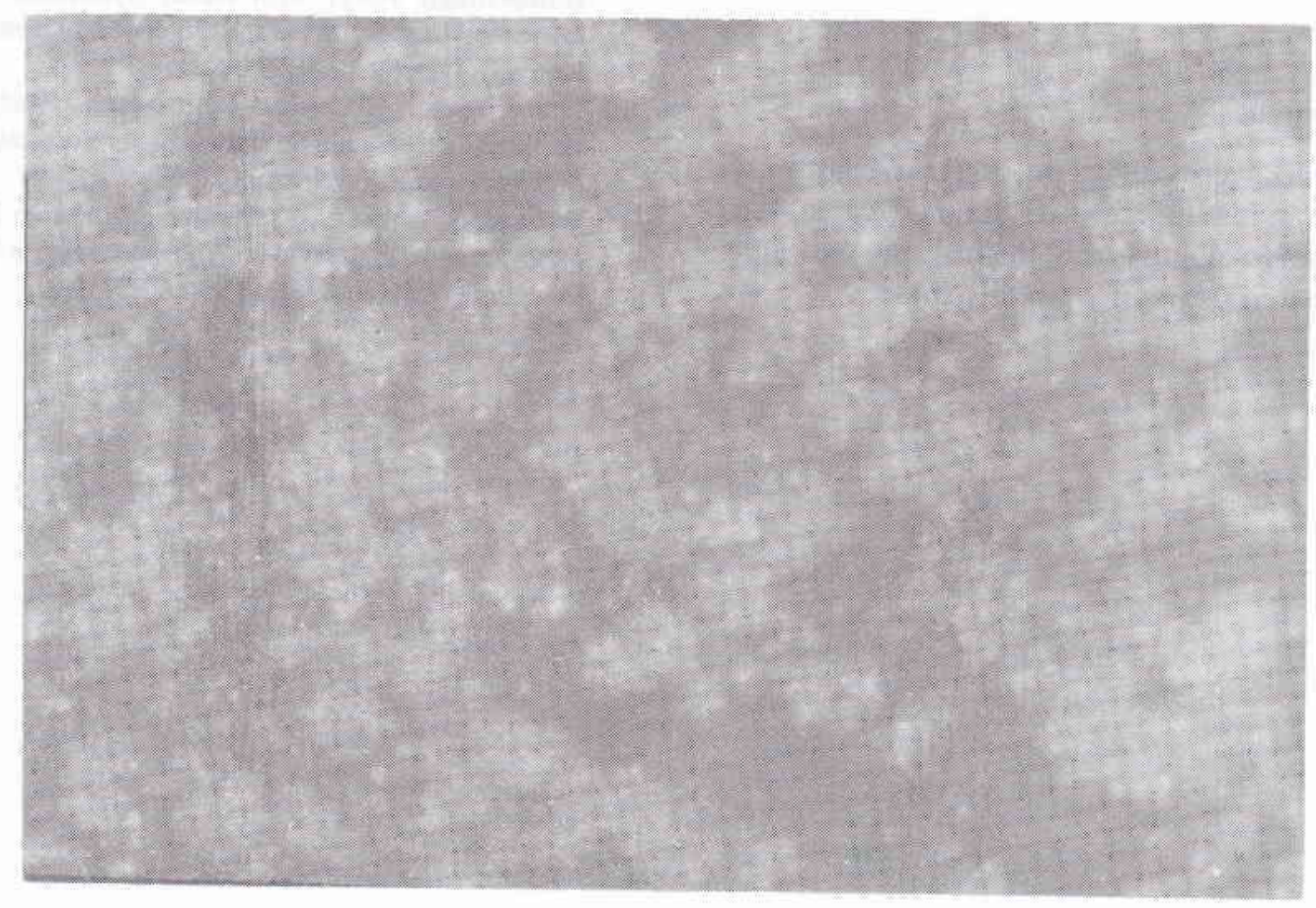

Figure I. Specific fluorescence of hantavirus antigen in Vero E6 cell stained by indirect immunofluorescence antibody test. Characteristic discrete fine granules are viral antigens after 15 days inoculation. Magnification X 400 . 
Different strain of hantavirus may cause infection with different signs and symptoms. Infection with Puumula virus has been associated with nephritis without hemorrhagic manifestations, whereas Seoul virus causes mild forms of HFRS.

It was reported in Singapore that infections with hantavirus were found in $10 \%$ of cases of suspected dengue fever, $5 \%$ cases suspected leptospirosis, and $1 \%$ cases of hepatitis. ${ }^{8}$ Previous study by Supardi in Bandung showed that more than $50 \%$ cases of clinically dengue fever were seronegative when confirmed by hemagglutination inhibition test. ${ }^{10}$ In a similar study conducted in Jakarta by Wuryadi showed that seronegative were found in $46.3 \%$ of suspected dengue fever. ${ }^{11}$ It is possible that infection with hantavirus might have occured in these cases.

Differential diagnosis of infection with hantavirus includes hepatitis, nephritis, leptospirosis, dengue hemorrhagic fever, pneumonia, and septicaemia. ${ }^{3}$ Thus, diseases with clinical features resemble to them should be examined for possible hantavirus infection.

Since the main reservoir of hantavirus is wild rats, and our environment, especially in slum areas, is still densely populated with the animals, the existence of hantavirus could be an emerging viral infection problem in Indonesia.

\section{Acknowledgement}

Parts of this work were carried out at The Department of Virology Asan Institute for Life Science Korea. We thank Professor Ho-Wang Lee of the Institute for kindly providing materials required in this study.

\section{REFERENCES}

1. Lee HW, Lee PW, Baek LJ, Chu YK. Geographical Distribution of Hemorrhagic Fever and Renal Syndrome and Hantaviruses. Arch Virol 1990 (Suppl. 1):5-18.

2. Hemorrhagic Fever with Renal Syndrome: memorandum from a WHO meeting. Bull WHO 1982;61:269-75.

3. Lee HW and van deer Groen G. Hemorrhagic Fever with Renal Syndrome. Prog Med Virol 1989;36:62-102.

4. Hjelle B, Jenison S, Martinez NT, Yamada T, Nolte K, Zumwalt R, Innes K, Myers G. A Novel Hantavirus Associated with an Outbreak of Fatal Respiratory Disease in The Southwestern United States. J Virol 1994;68(2):592-6.

5. Schmal John AL, Li D, Negley DL, Bressler DS, Turrel MJ. Isolation and Initial Characterization of a Newfound Hantavirus from California. Virol 1995;206:963-72.

6. Niklasson BS. Hemorrhagic Fever with Renal Syndrome, Virological and Epidemiological Aspects. Peditr Nephrol, 1992;6(2):201-4.

7. Lee PW, Meegan JM, Tkachenko EA, Kitamura T. Serologic Techniques for Detection of Hantavirus Infection, Related Antigens and Antibodies, in Lee HW and Dalrymple JM (eds). Manual of Hemorrhagic Fever with Renal Syndrome. WHO Collaborating Center for Virus Reference and Research. Seoul, Korea University 1989:75-110.

8. Wong TW, Chan YC, Joo YG, Lee HW, Lee PW, Yanagihara R. Hantavirus Infection in Humans and Commensal Rodents in Singapore. Trans R Soc Trop Med Hyg. 1989;83(2):248-51.

9. Chun CH, Laehdevirta J, Lee HW. Clinical Manifestations of HFRS, in Lee HW and Dalrymple JM (eds). Manual of Hemorrhagic Fever with Renal Syndrome. WHO Collaborating Center for Virus Reference and Research. Seoul, Korea University 1989;19-38.

10. Imam Supardi, Kosasih. A Retrospective Study on Dengue Hemorrhagic Fever in St. Bartolomeus Hospital of Bandung. Mikrobiologi Klinik Indonesia. 1989;7:88-91.

11. Wuryadi S. Isolasi Virus Dengue dari Pasien Demam Berdarah Dengue Pada Waktu Wabah di Jakarta Tahun 1988. Cermin Dunia Kedokteran 1990;60:27-30. 